WellBeing International

WBI Studies Repository

1-15-2009

\title{
The effects of the acetic acid "pain" test on feeding, swimming, and respiratory responses of rainbow trout (Oncorhynchus mykiss): A critique on Newby and Stevens (2008)
}

Lynne U. Sneddon

University of Liverpool

Follow this and additional works at: https://www.wellbeingintlstudiesrepository.org/acwp_arte

Part of the Animal Studies Commons, Other Animal Sciences Commons, and the Veterinary

Toxicology and Pharmacology Commons

\section{Recommended Citation}

Sneddon, L. U. (2009). The effects of the acetic acid "pain" test on feeding, swimming, and respiratory responses of rainbow trout (Oncorhynchus mykiss): a critique on Newby and Stevens (2008). Applied Animal Behaviour Science, 116(1), 96-97.

This material is brought to you for free and open access by WellBeing International. It has been accepted for inclusion by an authorized administrator of the WBI Studies Repository. For more information, please contact wbisr-info@wellbeingintl.org.

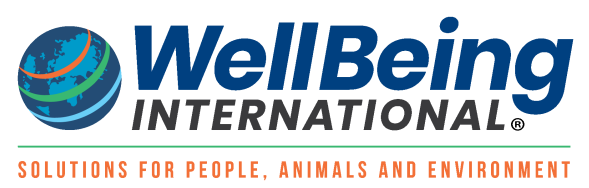




\section{Letter to the Editor - Applied Animal Behaviour Science}

The effects of the acetic acid "pain" test on feeding, swimming, and respiratory responses of rainbow trout (Oncorhynchus mykiss): A critique on Newby and Stevens (2008)

Newby and Stevens' (2008) paper "The effects of the acetic acid 'pain' test on feeding, swimming, and respiratory responses of rainbow trout (Oncorhynchus mykiss)" examines the effects of a noxious stimulus on the behaviour of trout in an attempt to replicate research conducted in my laboratory (Sneddon, 2003a; Sneddon, 2007; Sneddon et al., 2003a,b; Reilly et al., 2008). However, the authors used a different protocol to the one already published and I would like to respond to some of their points of discussion to provide scientific explanations for their results using data from my laboratory. The authors show that swimming behaviour and time to resume feeding are not impaired by administering $2 \%$ and $5 \%$ acetic acid subcutaneously but the fish do show the classic rise in respiration rate that has already been published. Recent electrophysiological investigations from my group have demonstrated that applying $2 \%$ acetic acid topically destroys nociceptor output and the neuron effectively dies (Ashley et al., 2006, 2007). Therefore, the lack of anomalous rubbing behaviours and resumption of feeding in the Newby and Stevens (2008) experiment can be attributed to them injecting such a high concentration of acid. If no nociceptive information is being conducted to the central nervous system then no behavioural changes will be elicited. This demonstrates the importance of following the experimental design of published studies to get comparable results (Sneddon, 2003a; Sneddon, 2007; Sneddon et al., 2003a,b; Reilly et al., 2008).

The authors also used a completely different housing design where fish where held in barren, cylindrical tanks rather than standard, rectangular tanks with gravel. This may preclude the ability to perform behaviours such as rocking, where the fish is situated on a gravel substrate and rocks to and fro on either pectoral fin (Sneddon et al., 2003a), and rubbing where the fish rubs the injection site into the gravel and sides of tanks (Sneddon, 2003a; Sneddon et al., 2003a; Reilly et al., 2008). If the tanks are cylindrical without flat surfaces or gravel, there is no substrate for the animals to perform these behaviours. Our research has also demonstrated that rainbow trout do not perform anomalous behaviours or exhibit such high physiological alterations in a barren environment as they do in an enriched environment. This data was presented at the International Fish Biology Conference (2006), the International Applied Animal Behaviour Conference (2006) and at the Society for Experimental Biology Meeting (2007; Sneddon, 2007). The authors, Newby and Stevens, were present during the 2006 spoken presentation at the International Fish Biology Conference in St. John's, Canada and discussed the results with us. Therefore, they are well aware that these behaviours are not performed in a barren tank set up. We have shown that barren conditions are more stressful for rainbow trout and result in higher levels of plasma cortisol. These stressful conditions result in increased preopiomelanocortin (POMC) in the brain of these noxiously stimulated trout but not in saline injected control fish (Sneddon et al., submitted for publication). POMC is the precursor to beta-endorphin and the enkephalins which act as natural painkillers within the nervous system of vertebrates in a mechanism called stress-induced analgesia (McNally, 1999). Therefore, the stress of being injected with a noxious stimulus using forcible restraint coupled with being held in a barren environment in the Newby and Stevens (2008) study would lead to high-cortisol levels (Arends et al., 1999) as demonstrated by the loss of equilibrium in the noxiously stimulated fish. This most likely led to stress-induced analgesia since high cortisol results in the release of betaendorphin in fish (van den Burg 
et al., 2005) and, therefore, no suspension in feeding or performance of pain-related behaviours was observed as pain would be reduced centrally. Again, it is vital to follow established experimental protocol to obtain similar results (Sneddon, 2003a; Sneddon, 2007; Sneddon et al., 2003a,b; Reilly et al., 2008).

The Newby and Stevens' (2008) study raises a very serious ethical point about the treatment of animals in pain experimentation. In their protocol, they restrain trout without anaesthesia and insert a hypodermic needle into a very sensitive area of skin innervated by nociceptors (Sneddon, 2002, 2003b; Ashley et al., 2006) and administer a high concentration of damaging substance. I believe that this is not a humane way to administer such a noxious substance given that fish are aquatic animals and removing them from the water is effectively suffocating them causing significant stress (Arends et al., 1999). The ethical guidelines followed by this journal state that "Procedures with animals that may cause more than momentary or minimal pain or distress should be performed with appropriate sedation, analgesia, or anesthesia in accordance with accepted veterinary practice. Surgical or other painful procedures should not be performed on unanesthetized animals" (http://www.cioms.ch/frame_1985_texts_of_guidelines.htm). I believe that these guidelines should be adopted in future studies concerning pain in aquatic animals and that appropriate anaesthesia should be used when administering noxious stimuli.

\section{References}

Arends, R.J., Mancera, J.M., Munoz, J.L., Bonga, S.E.W., Flik, G., 1999. The stress response of the gilthead sea bream (Sparus aurata L.) to air exposure and confinement. J. Endocrinol. 163, 149-157.

Ashley, P.J., Sneddon, L.U., McCrohan, C.R., 2007. Nociception in fish: stimulus-response properties of receptors on the head of trout Oncorhynchus mykiss. Brain Res. 1166, 47-54.

Ashley, P.J., Sneddon, L.U., McCrohan, C.R., 2006. Properties of corneal receptors in a teleost fish. Neurosci. Lett. 410, 165-168.

McNally, G.P., 1999. Pain facilitatory circuits in the mammalian central nervous system: their behavioral significance and role in morphine analgesic tolerance. Neurosci. Biobehav. Rev. 23, 1059-1078.

Newby, N.C., Stevens, E.D., 2008. The effects of the acetic acid "pain" test on feeding, swimming, and respiratory responses of rainbow trout (Oncorhynchus mykiss). Appl. Anim. Behav. Sci. 114, 260-269.

Reilly, S.C., Quinn, J.P., Cossins, A.R., Sneddon, L.U., 2008. Behavioural analysis of a nociceptive event in fish: comparisons between three species demonstrate specific responses. Appl. Anim. Behav. Sci. 114, 248-259.

Sneddon, L.U., 2002. Anatomical and electrophysiological analysis of the trigeminal nerve of the rainbow trout, Oncorynchus mykiss. Neurosci. Lett. 312, 167-171.

Sneddon, L.U., 2003a. The evidence for pain perception in fish: the use of morphine as an analgesic. Appl. Anim. Behav. Sci. 83, 153-162.

Sneddon, L.U., 2003b. Trigeminal somatosensory innervation of the head of the rainbow trout with particular reference to nociception. Brain Res. 972, 44-52.

Sneddon, L.U., Braithwaite, V.A., Gentle, M.J., 2003a. Do fish have nociceptors: evidence for the evolution of a vertebrate sensory system. Proc. R. Soc. Lond. B 270, 1115-1122. 
Sneddon, L.U., Braithwaite, V.A., Gentle, M.J., 2003b. Novel object test: examining pain and fear in the rainbow trout. J. Pain 4, 431-440.

Sneddon, L.U., Edwards, K.L., Ringrose, S., Oulton, L.J., Ashley, P.J., McCrohan, C.R., submitted for publication. Evidence for central processing of pain in fish: stress induced analgesia.

van den Burg, E.H., Metz, J.R., Spanings, F.A.T., Bonga, S.E.W., Flik, G., 2005. Plasma alpha-MSH and acetylated beta-endorphin levels following stress vary according to $\mathrm{CRH}$ sensitivity of the pituitary melanotropes in common carp Cyprinus carpio. Gen. Comp. Endocrinol. 140, 210-221.

Lynne U. Sneddon*

University of Liverpool, School of Biological Sciences

The BioScience Building, Liverpool L69 7ZB, UK

*Tel.: +44 151795 4383; fax: +44 1517954431

E-mail address: Isneddon@liverpool.ac.uk 